\title{
ESCRITA E CONVERSÃO NA ÁFRICA CENTRAL DO SÉCULO XVII: O CATECISMO KIKONGO DE 1624.
}

\author{
José Rivair Macedo* \\ jrivair@uol.com.br
}

RESUMO: Desde os séculos XIII-XIV, momento em que ocorreu o primeiro movimento missionário de conversão dos povos pagãos no Oriente, uma das condições para a evangelização era o conhecimento das línguas dos povos não cristãos. Nos tempos modernos, um grande esforço foi dedicado ao aprendizado de línguas nativas das Índias Orientais, do Novo Mundo e da África, com sua respectiva literalização e aplicação na obra catequética pelos padres da Companhia de Jesus. Pretende-se enfatizar este último aspecto a partir do estudo introdutório do catecismo dialogado denominado Doutrina Christã, escrito em 1566 pelo Pe. Marcos Jorge, na Europa, e adaptado para a língua Kikongo durante o trabalho de evangelização dos povos do antigo reino do Congo ao longo do século XVII.

PALAVRAS CHAVE: Conversão, catecismo kikongo, África, século XVII.

Na seção dos reservados da Biblioteca Nacional de Portugal, em Lisboa, encontra-se um documento pouquíssimo conhecido dos africanólogos, o catecismo intitulado Doutrina Christã, do padre Marcos Jorge, em edição bilíngue português-kikongo. A obra contém 13 capítulos, em que se alternam redações nas duas línguas, linha a linha, em um total de 133 fólios ${ }^{1}$. Trata-se ao que parece da primeira experiência de literalização de uma língua africana para a grafia ocidental, latina, com a finalidade de ensinar o catolicismo às populações da África central, para sua evangelização e conversão. Apresentaremos a seguir alguns aspectos deste documento, do contexto em que foi produzido e suas implicações na história dos primeiros contatos histórico-culturais entre europeus e centro-africanos.

\section{CONQUISTA E CONVERSÃO}

\footnotetext{
* Professor de História da África no Departamento de História e no PPG de História da UFRGS; Sócio-correspondente da Academia Portuguesa da História; o presente estudo vincula-se ao projeto "Portugueses e africanos no contexto da abertura do Atlântico", com financiamento de Bolsa de Produtividade em Pesquisa do CNPQ.
} 
A Expansão Marítima, com a consequente ampliação de contatos na África, Ásia e América recolocou em outros termos a questão da evangelização e conversão de povos pagãos de uma espécie diferente daqueles com que as lideranças cristãs estavam de algum modo habituadas. Esses não eram mais povos herdeiros do paganismo greco-romano ou celta-germânico, cujas crenças desde muito cedo entraram em franco processo de simbiose com o cristianismo, ou foram se anquilosando, mas de grupos que, absolutamente alheios à doutrina cristã, encontravam-se ou num estágio de pureza edênica ou entregues a uma condição de "selvageria" que era necessário dar combate espiritual. O meio escolhido foi sempre o da missionação, e os agentes mais bem sucedidos na tarefa pertenciam à Companhia de Jesus.

A estratégia adotada pelos primeiros missionários cristãos na África seguia o exemplo dos primeiros missionários latinos no mundo extra-europeu desde o século XIII. As obra da conversão começava pelos chefes locais, cujo apoio era condição imprescindível para o estabelecimento de núcleos religiosos e para o combate às lideranças religiosas tradicionais. Depois, vinha o esforço no ensinamento da língua latina e o aprendizado das línguas locais, sem o qual não seria possível transmitir os novos valores e princípios que se pretendia difundir (CURTO, 2009 , pp. 38-42) $)^{2}$. Por tudo isso, o primeiro alvo dos missionários eram as crianças, e depois as mulheres, consideradas mais flexíveis aos ensinamentos, menos resistentes à recepção do cristianismo.

A irradiação do cristianismo na África central se fez a partir do Congo, devido aos esforços empreendidos pelos próprios manicongos que, desde os primeiros contatos, viram na aproximação com os portugueses e com o seu modelo de vida uma estratégia de afirmação política. No governo de Mvemba-a-Nzinga, mais conhecido pelo nome cristão de Afonso I (c. 1456-1543), o cristianismo passou a ser a religião oficial do reino, com a proibição das religiões tradicionais e o culto aos fetiches - que levou ao movimento conhecido como "Revolta da casa dos ídolos". Inspirando-se no regimento de governo enviado em 1512 pelo monarca português Manuel I, uma série de modificações internas foram introduzidas no Congo, com a difusão de títulos de nobreza e o empréstimo de símbolos de poder de proveniência européia ${ }^{3}$.

Envolvido em conflitos internos que se sucederam à morte de Afonso I, o reino do Congo sofreria forte abalo em 1568, quando suas populações foram atacadas e parcialmente massacradas por um grupo nômade de guerreiros que ficaram notabilizados pelo nome de jagas. Para fazer face a eles, o Congo necessitou da ajuda de tropas européias e suas armas de fogo, e José Rivair Macedo. Escrita e conversão na África Central do século XVII: o catecismo Kikongo de 
depois de passada a tormenta das invasões, a pressão dos traficantes de escravos luso-africanos sediados na Ilha de São Tomé e dos representantes da monarquia lusa aumentaram. Nas primeiras décadas do século XVII os manicongos tentaram aproximar-se de outras nações européias, como a França, Roma e os Estados italianos, e inclusive a Holanda, para contrabalançar a influência dos portugueses em suas áreas de influência (VANSINA, 1965, pp. 100-110; RANDLESS, 1968, pp. 129-134).

Mais para o Sul, no Ndongo, os contatos com os europeus não foram tranquilos, e a incorporação se fez por meio da conquista armada. A primeira investida, de 1520-1526, falhou e foi socorrida pelo manicongo Afonso I, o mesmo ocorreu com a campanha de 1560-1564, e em 1571, com a concordância do manicongo Álvaro I (1568-1648), o militar português Paulo Dias de Novais e suas tropas adentraram no território, apoiados na fortaleza de São Paulo de Luanda, fundada em 1576. Articulando uma política de negociação diplomática com os chefes tradicionais das unidades políticas menores, os sobas, de imposição militar aos adversários dos interesses portugueses, e de expansão do catolicismo por meio da atividade missionária, o Ndongo foi aos poucos sendo efetivamente incorporado aos domínios coloniais portugueses, com os sobas reduzidos à condição de vassalagem e ao pagamento de tributos, situação que assinala o ponto de partida da posterior província de Angola (BIRMINGHAM, 2008, pp 187-217, esp. pp. 197-198).

Nessas condições, era de se esperar que a implantação do catolicismo não tivesse sido fácil na região de Ndongo. Só com o apoio prestado por alguns manicongos, por meio de guerras promovidas com o auxílio dos guerreiros jagas provenientes dos grupos de mbangalas, e com o recurso a mercenários com armas de fogo, sua supremacia foi aos poucos sendo garantida. A submissão e aceitação do batismo pelos sobas equivalia ao reconhecimento da superioridade portuguesa - garantida com a construção de fortes como os de Massangano e Cambambe (VANSINA, 1965, pp. 100-110). Logo depois, partiria dos sobas o fornecimento regular de cativos para o lucrativo tráfico transatlântico de escravos. Segundo o testemunho de Baltasar Rebelo de Aragão, que participou de uma expedição militar no Ndongo organizada pelo governador Francisco de Almeida em 1592, o resgate de escravos passou a ser o principal motivo da pressão dos portugueses sobre as lideranças locais do Ndongo (CORDEIRO, 1935, p. 224).

Paralelamente à conquista político-militar o Ndongo foi sendo incorporado ao cristianismo, num movimento de conquista espiritual em que os jesuítas tiveram protagonismo inicial e os capuchinhos franciscanos assumiram papel de maior relevo a partir da década de 1640 .

Hist. R., Goiânia, v. 18, n. 1, p. 69-90, jan. / jun. 2013 
Em seu relatório datado de novembro de 1619 o frei franciscano Manuel Baptista informava que, na ocasião, havia 24 sacerdotes em todo o Congo, e que em Luanda havia um vigário geral, um coadjutor, uma casa com 9 jesuitas e um convento com quatro ou cinco franciscanos. Os jesuitas tinham se instalado em Luanda no final do século XVI, e sua missão evangélica esteve desde muito cedo vinculada ao ensino. As aulas na escola primária começaram em 1604, e constituem o ponto de partida da formação do Colégio de Luanda. Em 1625 abririam um novo colégio, dessa vez em São Salvador do Congo, com dois ou três religiosos. Era daí que partiam para realizar sua obra missionária nas chefaturas de Bengo, Pungo, e na região de Benguela (REMA, 1997, pp. 525-526).

Para a reconstituição do contexto em que se deu a implantação inicial dos jesuitas na África, um testemunho de excepcional qualidade são os anais do padre Fernão Guerreiro. A julgar por suas informações, a ação jesuítica foi bem mais modesta do que a posterior missão dos capuchinhos, que seria iniciada algum tempo depois, em meados do século XVII e que contou com contenas de missionários, à serviço da Propaganda Fide - vinculada diretamente à Santa sé. Entre 1605-1606 apenas dois sacerdotes, o padre Gaspar de Azevedo e o irmão António de Sequeira, tentaram evangelizar os sobas, convertendo as crianças e destruindo as casas dos ídolos cultuados tradicionalmente por aquelas populações. Segundo ele, grandes possíbilidades de evangelização se apresentaram aos missionários, pois em Ndongo estariam as pessoas mais predispostas da África a receber a nova fé:

Por que são de muito bons entendimentos, posto que para os que ñ entendem sua língua sejam tidos por boçais, como eles nos teem também a nós por não entenderem a nossa, e assim trabalham os padres muito por aprender sua língua, porque sabendo-a e entendendo-se com eles, nenhuma dificuldade haverá em os fazerem todos cristãos, e não somente aos do reino de Angola, mas os dos outros reinos vizinhos e comarcãos, cujos reis por vezes mandaram já pedir ao governador que eles queriam ser cristãos com toda sua gente, que lhes mandassem padres para os ensinarem e batizarem, mas que fossem daqueles que não teem mulheres em casa. Donde se pode ver quão disposta esteja esta gente para receber nossa santa fé, se houver ministros de Deus que lha preguem. Na casa que a Companhia aqui tem não há mais que três sacerdotes e dois ou três irmãos, por serem falecidos os mais e que eram os melhores línguas que lá viviam e dos principais obreiros (VIEGAS, 1930, p. 398).

Da longa passagem convém sublinhar três idéias principais: 1) a predisposição das lideranças de Ndongo para receber o cristianismo; 2) o aprendizado das línguas como condição José Rivair Macedo. Escrita e conversão na África Central do século XVII: o catecismo Kikongo de 
para o sucesso da empreitada; 3) o ínfimo contingente de missionários, principalmente aqueles com domínio das línguas locais, o que dificultava o trabalho da conversão. Embora cada uma dessas idéias deva ser submetida ao crivo da análise histórica, reteremos apenas aquela concernente ao papel do aprendizado das línguas, pois é aí que se insere muito provavelmente a elaboração do catecismo bilíngue aqui estudado. Mas antes de refletir sobre as implicações culturais da transliteração de signos linguísticos e religiosos, vale a pena reservar algum espaço para a recomposição da genealogia intelectual dos catecismos católicos em solo extra-europeu.

\section{CATECISMOS TRIDENTINOS}

A elaboração dos catecismos foi um meio previlegiado de difusão da doutrina cristã desde os tempos medievais. Eram o prolongamento de obras didáticas muito antigas, entre as quais o Elucidarium de Honório de Autun (1095), o Dialogus Miraculorum de Cesário de Heisterbach e o Lucidario, compilação extraída de fontes latinas, de caráter enciclopédico, pastoral e doutrinal, do tempo de Sancho IV de Castela (1258-1295) (KINDALE, 1968). Em, Portugal, gozava de grande o prestígio o Cathecismo pequeno, do clérigo castelhano Diogo Ortiz de Vilhegas, elaborado no final do século XV e impresso com autorização real em 1504, em caracteres góticos e várias iniciais ornadas através dos fólios. Junto com uma Cartinha, ou Cartilha do final do século XV, que se encontra na seção de reservados da Biblioteca Nacional de Portugal (Res. 5567P), este situa-se entre as obras mais antigas destinadas ao ensinamento religioso das crianças (CRISTOVÃO, 1998).

A difusão dos catecismos no Novo Mundo remonta aos primórdios da ocupação do seu território pelos europeus. Já nas primeiras décadas do século XVI imprimiam-se na Espanha materiais deste tipo, como o Dialogo de la doctrina Christiana, de Juan de Valdés (1529) e a Suma de la Doctrina Christiana, de Constantino Ponce de la Fuente (1543). Pouco antes, concluía-se em Sevilha a Doctrina en lengua de Índios de Mechuacán, do bispo Vasco de Quiroga (1538), que parece ter constituído a primeira experiência de transliteração do discurso religioso europeu para uma língua não-européia. Todavia, a operação itnelectual da transliteração trazia consigo riscos linguísticos praticamente incontornáveis, algo que as autoridades logo perceberam, pois uma ordenação fixada em Valladolid em 22/09/1538 submetia ao exame de um tribunal eclesiástico um catecismo vertido para a língua indígena: "E avertid mucho en que los que lo examinaren que 
miren que los vocablos no traingan inconvenientes para la doctrina y religion cristiana, por las significaciones que los indios en su lengua les dan" (MARTINES, 1989, p. 427).

A codificação e padronização dos elementos retóricos e doutrinais dos catecismos aumentou significativamente após a redação do catecismo tridentino, promulgado e difundido sob o pontificado de Pio V (1568). Algumas obras do gênero que gozavam até então de grande popularidade, como a Suma de la Doctrina Christiana, de Constantino Ponce de la Fuente, foram postas de lado depois de terem sido condenadas e proibidas pelos tribunais da Inquisição. $\mathrm{Na}$ primeira metade do século XVII o papa Urbano VIII determinou, através da bula ex debito pastoralis, de 22/02/1633, que os missionários ensinassem e instruissem os cristãos uniformemente, através do Catecismo Romano de Doutrina Cristã do Cardeal Roberto Belarmino (1542-1621) (MARTINS, 1951, pp. 18-20), fazendo traduzir essa obra em diversas línguas

$\mathrm{O}$ interesse pelo conhecimento das línguas locais continuou, e os jesuitas foram os seus principais promotores na América, Ásia e na África (ZWARTJES, 2011). No Brasil, a iniciativa mais conhecida nesse sentido deve-se a redação por José de Anchieta da Arte Gramática da Lingua mais Usada na Costa do Brasil, concluida provavelmente em 1556, e impressa no Colégio da Bahia em 1595. O conhecimento da língua tupi, cujas variantes foram agrupadas e homogeneizadas naquela que viria a ser chamada de "língua geral", seria um meio de instrumentalização dos catecúmenos no serviço espiritual da evangelização (ANCHIETA, 1999, pp. 232-236). Do outro lado do Atlântico, a sistematização e continuidade das atividades ligadas ao tráfico de cativos africanos produziu o fenômeno de aglutinação linguística e a criação de "línguas gerais" de grande alcance, na África e fora dela. Foi o caso dos falares de origem banto da África central, que se fundiram em línguas de maior difusão, como o kikongo, o mbundo e o kimbundo (PETTER, 2011, pp. 78-96; BONVINI, 2008, pp. 15-62). Coube, igualmente a um jesuita, o padre Pedro Dias, a redação em 1697 do primeiro estudo da gramática da língua quimbundo, falada pelos escravos provenientes da África central na Bahia, e inclusive por europeus e luso-brasileiros, para a instrumentalização da catequese (ROSA, 2010).

$\mathrm{Na}$ Europa, também eram os jesuitas os autores mais frequentes de catecismos e de gramáticas nos séculos XVI-XVII. Nos domínios germânicos, utilizava-se com frequência o catecismo de Pedro Canisto (1556), na Espanha o de Jeronimo Ripalda (1591) e Gaspar Astete (1593), nas comunidades italianas o de Roberto Belarmino (1597) e em Portugal o dos padres Marcos Jorge (1566) e Ignacio Martinz - que o revisou e acrescentou algumas passagens ${ }^{4}$. A obra José Rivair Macedo. Escrita e conversão na África Central do século XVII: o catecismo Kikongo de 1624. 
de Marcos Jorge torna-se particularmente importante porque serviu de base para muitas adaptações de catecismos no ultramar português. Seu texto foi vertido para a língua tupi pelo jesuita Leonardo do Vale em 1574, para a língua tamul (de Malabar) (ZUPANOV, 1998) pelo padre Henrique Henriques em 1579, para a língua japonesa no ano de 1592, para a língua concani (da Índia) pelo padre Thomas Estevão em 1622, e em língua kikongo pelo padre Matheus Cardoso em 1624 (BARROS, 2003).

Desde modo, como a pesquisadora Cândida Barros sublinha, a difusão da obra de Marcos Jorge, com as adaptações e acréscimos feitos pelo mestre em teologia Ignacio Martinz, foi parte de uma política jesuítica de disciplinarização pelos cânones do Concílio de Trento, visando enquadrar a evangelização pelo modelo usado em Portugal. Como metodologia de ensino, adotava o recurso retórico do diálogo sucessivo de perguntas e respostas entre um mestre (padre) e um discípulo (menino) hipotéticos, de onde sua qualificação como "catecismo dialogado" (BARROS, 2008, p. 13). Destinava-se, no reino, às crianças e aos incultos, e aos povos ultramarinos.

\section{O CATECISMO KIKONGO}

O kikongo era a língua mais difundida no antigo reino do Congo, pertencente à extensa família linguística bantu. No catecismo de 1624 ela aparece nomeada, literalmente, como "lingua do Congo" ou de "Mucicõgo". Atualmente, é falada por uma população estimada em mais de 3 milhões de pessoas, pertencentes especialmente ao grupo bakongo que habita o Noroeste de Angola, o Sudoeste da República Democrática do Congo e o extremo Sudoeste da República do Congo (Brazzaville) (MANUEL, 2002; TAVARES, 1934) ${ }^{5}$. A partir do século XVI, em virtude do estreitamento de contato com os portugueses, teria ocorrido, nas palavras do linguista Emílio Bonvini uma dupla "revolução tecnológica" que consistiu na transferência do alfabeto latino às línguas africanas, e sua gradual fixação por escrito, com a subsequente criação das primeiras gramáticas do kikongo e do kimbundu (BONVINI, 1996; RANDLESS, 1968). Paralelamente, a língua portuguesa passou a ser apropriada pelos falantes das línguas bantu, numa lenta mas progressiva aquisição dos recursos da escrita européia pelas elites africanas - que passou gradualmente a ser empregada como veículo de comunicação nas relações diplomáticas desde os séculos XVI-XVII (FERRONHA, 1992; TAVARES, SANTOS, 2002; SANTOS, 2006; THORTON, 1996) ${ }^{6}$. 
Neste amplo quadro de encontros e trocas culturais, o fato de que o documento aqui examinado seja apenas uma reprodução do catecismo tridentino não elimina de todo sua originalidade documental. Mais do que um testemunho linguístico da apropriação da escrita dos, e pelos africanos, o catecismo kikongo de 1624 revela pontos específicos do tipo de catolicismo que se pretendia implantar no Congo e em Ndongo. Por seu intermédio se pode avaliar, por um lado, os limites e possibilidades da evangelização, e por outro lado, os traços sócio-religiosos e sócioculturais resultantes dos primeiros contatos entre europeus ibéricos e centro-africanos.

Em apoio desta hipótese, basta comparar a estrutura textual de uma versão portuguesa com a do catecismo kikongo, o que se pode fazer a partir do cotejamento com o exemplar de 1616, disponível no acervo da Bayerische Bibliothek, em Munique, Doutrina christam ordenada a maneira de dialogo para ensinar os mininos. O que se constata de imediato é que o mesmo conteúdo encontra-se distribuído nos dois catecismos, mas a forma e a dimensão não são sempre as mesmas. A edição lusa está dividida em 13 capítulos breves, que reaparecem literalmente na edição bilingue português-kikongo. Os dois primeiros capítulos expõem os fundamentos essenciais do cristianismo, com definições e indicações dos símbolos da crença. Seguem-se as orações (padrenosso; credo; ave-maria e salve-rainha), os fundamentos morais da doutrina (artigos de fé; mandamentos; enunciação dos pecados capitais e dos sacramentos) e orientações práticas da vida espiritual (boas obras; frequência à missa; realização de orações). Quanto à forma, uma diferença digna de nota diz respeito ao amplo uso de imagens de apoio ao texto na versão portuguesa, em flagrante contraste com a completa ausência delas na versão destinada aos africanos.

O catecismo em kikongo é antecedido de uma carta endereçada ao reino do Congo D. Álvaro III (1615-1622), que ilustra de modo claro a estratégia de evangelização adotada pelos jesuitas do Colégio de Luanda. A figura do monarca é louvada e se reconhece nela um espelho moral para todo o Congo e o Ndongo. Além do apoio prestado aos padres, seu comportamento é tido como exemplar: pela fidelidade demonstrada aos preceitos cristãos; pela submissão a esses preceitos ao evitar a poligamia e ao demonstrar publicamente humildade pessoal (dispensando, por exemplo, o uso de guarda-sol em caminhadas); pela difusão desses preceitos ao corrigir os súditos que permaneciam na idolatria e ao incentivar os costumes cristãos, entre os quais aqueles vinculados ao enterramento. Seguia-se aqui em tudo a orientação oficial existente na Igreja desde o tempo da evangelização dos germanos, que consistia, primeiro, na conversão dos chefes para, 
depois, com a intervenção direta destes, destruir os ídolos e iniciar o trabalho de evangelização da população.

Outra diferença textual significativa diz respeito à parte final do catecismo kikongo, onde se encontra uma longa parte reservada às práticas da confissão e aos comportamentos desejáveis do bom cristão, pouco desenvolvida na edição portuguesa de 1616. Deve corresponder muito provavelmente ao conteúdo introduzido pelo teólogo Ignacio Martinz, e nada acrescentado diz respeito diretamente a práticas específicas das populações do Congo. São antes informações complementares sobre o modo ideal de comportamento e vivência religiosa do bom cristão, e um conjunto de orações, inclusive indicações de como rezar o rosário (DOUTRINA CHRSTÃA, fol. 78-104).

O maior interesse documental do catecismo kikongo diz respeito ao campo da linguística, e indiretamente ao âmbito das relações e trocas culturais. Sua originalidade reside no fato de que, pela primeira vez literalizava-se em um texto longo, em signos gráficos latinos, a língua kikongo (BONVINI, 1996, p. 139). Esta operação exigiu um esforço consideravelmente grande de todos os envolvidos, fossem os intérpretes, os escritores ou os leitores, porque a apropriação linguística implicava também na apropriação mental dos sistemas de valores de dois conjuntos culturais que apenas começavam a manter relações. Teria a associação linguística entre a língua portuguesa e a língua kikongo condições de expressar, para cada um desses conjuntos, significados equivalentes? Esta com certeza é a questão central colocada pela própria existência daquele que foi o primeiro catecismo africano. Nela reside sua singularidade como documento histórico e como testemunho do mundo atlântico afro-português.

Não se trata, portanto, de limitar sua leitura àquilo que é explicitado desde sua composição, isto é, aos elementos doutrinais que se pretendia inculcar no público de destino, pois os mesmos elementos são inscritos em documentos destinados aos europeus, asiáticos e ameríndios. Teríamos aí uma leitura rasa que ilustraria apenas o ponto de vista dos agentes culturais externos. Também não parece ser o caso de dirigir a atenção exclusivamente aos equivalentes cristãos da versão escrita em kikongo, como se ela constituisse um receptáculo passivo que pudesse ser rearranjada e reformada, manipulada e adequada a expressar valores que, em princípio, lhe eram estranhos. O potencial interesse está na mediação dos conceitos e fundamentos religiosos, cristãos e africanos, colocados em pauta no momento em que signos linguísticos distintos foram aproximados

Hist. R., Goiânia, v. 18, n. 1, p. 69-90, jan. / jun. 2013 
para tornar visível conceitos comuns que não tinham significados iguais em seus respectivos conjuntos culturais de origem.

Aqui, uma observação de caráter metodológico se faz necessária. O fato de que a evidência documental examinada tenha sido produzida por europeus não deve nos induzir ao erro de pensar que ele expressa apenas esse ponto de vista ${ }^{7}$. Mesmo que os sujeitos africanos não estejam presentes na enunciação do discurso, que é eminentemente estranho a eles, aí subsistem suas marcas indiretas, pois era a eles que o texto se destinava ${ }^{8}$. Será preciso ler nas entrelinhas o subtexto, no qual a presença cultural africana fazia a diferença, e considerar que a própria produção do documento dependeu da intervenção de enunciadores africanos, na qualidade de intérpretes, de mediadores culturais ${ }^{9}$, e do conhecimento dos sistemas de valores próprios das culturas de matriz bantu.

Ao considerar apenas o ponto de vista dos missionários, a primeira impressão - porque era essa que se desejava voluntariamente inculcar - é a de que as formas religiosas européias e as formas religiosas africanas fossem radicalmente diferentes, antitéticas, inconciliáveis. Caberia a uma delas substituir a outra, transplantando novos fundamentos e inculcando novas formas de conduta consideradas corretas, e à outra assimilar, receber, ser estruturalmene modificada ${ }^{10}$. Será esse o caso para a leitura dos documentos missionários como se eles constituíssem um monólogo. Outra perspectiva abre-se ao se considerar as informações de um ponto de vista relacional, como a expressão de um diálogo - mesmo que a voz de um dos sujeitos tenha que ser recuperada através do discurso do outro (ALMEIDA, 1997; SOUZA, 2006; GONÇALVES, 2008).

Em perspectiva relacional será forçoso reconhecer a existência de pontos de conexão entre ambas as formas religiosas, sem as quais não teria sido possível qualquer tipo de aproximação lingúistica e, por extensão, cultural, em seus enunciados gerais. Admite-se com muita frequência que o mais importante ponto de conexão tenha sido a crença comum entre europeus e africanos na existência de uma potência criadora universal, ser supremo e eterno, ordenador de todas as coisas do universo, de um preexistente que, na religião cristã recebe a denominação de Deus, e que nas tradições religiosas africanas recebe diferentes designativos (ALTUNA, 2006, p. 399) ${ }^{11}$. Esta correspondência profunda teria permitido a recepção, fusão e diálogo não apenas com o cristianismo, mas também com o judaísmo e o islamismo - de acordo com as diferentes áreas e épocas de contatos culturais (MONTEIRO, 1991).

José Rivair Macedo. Escrita e conversão na África Central do século XVII: o catecismo Kikongo de 1624. 
Não obstante as diferenças nos modos de organização religiosa (monoteista; politeísta; organizadas ou não em torno de instituições) e nas formas de expressão (escrita; oral; litúrgica; ritual), havia entre o catolicismo e as religiões africanas tradicionais pontos de intersecção, áreas de confluência de elementos comuns que permitiam a ocorrência de aproximações, coexistência e fusões entre elas. Embora a primeira fosse monoteísta e tivesse produzido um discurso identitário de alcance universal, este não se chocava complemente com as práticas politeístas e idolátricas das crenças locais africanas porque, abstraindo as diferenças de forma e expressão, algumas similaridades profundas as aproximavam (CORDEIRO, 1935, p. 232) ${ }^{12}$.

O desenvolvimento do cristianismo africano não teria sido possível sem tais intersecções e tais similaridades. A principal delas, segundo John Thorton, é a de que ambas as concepções religiosas partilhavam a idéia comum de que havia outro mundo que não podia ser visto, e as revelações eram a fonte indispensável pela qual as pessoas poderiam tomar conhecimento desse outro mundo (THORTON, 2004, p. 313). Milagre ou feitiço, profecia ou vaticínio, eucaristia ou libação aos espíritos dos ancestrais constituíam manifestações cujas diferença e valor variavam em grau dependendo de quem fosse o observador. Aos olhos dos

europeus, as práticas africanas eram enquadradas nos rótulos desvalorizantes de "idolatria", "feitiçaria" e "paganismo", mas e quanto às práticas cristãs aos olhos dos africanos? O catecismo nos permite vislumbrar aspectos desse olhar porque, para se fazer entender os agentes culturais externos tiveram que se valer de signos extraídos do léxico religioso africano e, ao fazê-lo, produziram um discurso novo em que os significados culturais passaram a ser, no mínimo, compartilhados.

\section{LÍNGUAS, CONTATOS E TROCAS}

Os catecismos bilingues são bons referenciais de estudo para o ambiente de trocas culturais porque em sua composição, a alternativa encontrada pelos reformadores religiosos para se fazer entender era a apropriação de elementos preexistentes da cultura que se pretendia reformar, através da inculcação ou apropriação de signos linguísticos. Normalmente, para exprimir em vernáculo idéias ou frases que, sendo desconhecidos, ou diferentes, nas religiões do ultramar, não possuíam vocábulo apropriado, os redatores ou tradutores dos catecismos antigos valeram-se de três alternativas linguísticas. A primeira consistia em adotar os próprios vocábulos de sua língua de

Hist. R., Goiânia, v. 18, n. 1, p. 69-90, jan. / jun. 2013 
origem, adaptando-as à fonética da língua nativa. A segunda era aproveitar certas palavras cuja forma, entonação e sonoridade fossem provenientes da língua nativa, mas pouco ou não empregadas, agregando-lhes significado cristão-europeu. A terceira, e mais tentadora, era a utilização de vocábulos conhecidos e correntes na língua nativa, para designar pessoas e coisas mais ou menos idênticas do cristianismo (VALENTE, 1973) ${ }^{13}$.

Das três, a terceira alternativa era a mais propensa a gerar fenômenos de colisão e confusão linguística, produzindo significativos desvios de significado em ambas as culturas mediadas pela palavra. Os riscos de incorrer em lapsos conceituais e doutrinais acabavam sendo grandes porque, embora semelhantes, a relação entre signo e significado não produzia resultados idênticos. Nos primeiros catecismos em línguas do ultramar o uso desses termos correlatos não foi bem recebido pelas autoridades religiosas européias e em alguns casos determinadas palavras tiveram que ser modificadas.

Nos primeiros catecismos vertidos ao tupi, os jesuitas empregavam o vocábulo Tupã para designar a essência de Deus, o que causou incômodo porque entre os tupinambás o vocábulo designava apenas um espírito de ordem inferior, o poder invisível expresso através do trovão e do relâmpago, não sendo o mais adequado para qualificar a potência suprema que é Deus (MÉTRAUX, 1950, p. 112) ${ }^{14}$. Dificuldade similar teve o padre Tomás Estevão ao verter a doutrina cristã para a língua concani, em Goa. Ele foi muito criticado por estabelecer a equivalência linguística entre termos fortes da lingua nativa, como vaicunttha, que designava em princípio a habitação do deus Vishnu, com a idéia judaico-cristã do paraíso, e por designar padres e sacerdotes com o vocábulo guru, relacionado aos iniciados espirituais e homens sábios das religiões indianas. Com o tempo, tais termos foram abandonados e substituídos, respectivamente, por suarga e padri (SALDANHA, 1949, p.35).

O teólogo Mateus Cardoso tinha ciência desses riscos assumidos ao se criar paralelismos linguísticos quando verteu o catecismo do padre Marcos Jorge ao kikongo. Tomou cuidado para não empregar termos locais na enunciação de elementos centrais da doutrina, mantendo inalterada a forma de vocábulos ou denominações como Cristo (Christo), Santa Cruz, Igreja Católica, Santo, Espírito Santo (Spirito Santo) e cruz. Sobre esses dois últimos, apresenta logo no preâmbulo da obra uma explicação que demonstra todo o cuidado para evitar associações indevidas ou propensas a gerar colisões lingúisticas e culturais:

José Rivair Macedo. Escrita e conversão na África Central do século XVII: o catecismo Kikongo de 1624. 
"Chamam os naturaes de Congo ao Spirito Sãto Santo Monho Aquissi e a cruz, iquetequêlo, dos quais não quis usar. Como nem tãbem de outras palavras, porque ñ explicão bẽ a natureza \& propriedades das cousas, porque Monho Auquissi quer dizer Alma Santa \& Alma Santa se pode chamar qualquer dos bem-aventurados, assim $\tilde{n}$ he palavra própria que signifique a terceira pessoa da Sãtissima Trindade. Iquetequêlo quer dizer forca. E bẽ se vê que ñ significa a cruz, pelo que me pareceu melhor usar das próprias palavras Spirito Santo \& cruz, e de outras que por brevidade deixo de apontar" (DOUTRINA CHRISTAÃ, fol. 1).

Pela explicação fica evidenciada a dificuldade da transposição lingüística. Não obstante houvessem termos em kikongo com significados próximos, a proximidade era apenas formal, não sendo providas do sentido preciso cristão e lhes faltava a ênfase desejada pelos missionários. A adoção de Santo Monho Auquissi reduziria o Espírito Santo à condição de um espírito qualquer da religião tradicional, a um nkisi, isto é, a um fetiche. A relação entre Iquetequêlo e cruz, por sua vez, prendia-se ao fato de que ambos os vocábulos designavam instrumentos de execução, já que a cruz representava primeiramente essa idéia. Mas faltava a correspondência profunda, a aura que revestia o simbolismo espiritual daquela que se mantinha desde a Antiguidade romana como a imagem mais difundida do cristianismo.

Para termos e idéias menos precisos, ou com menos riscos de confusão doutrinal, Mateus Cardoso não hesitou em emprestar vocábulos do léxico religioso kikongo, traduzindo, por exemplo, Deus por Zambiampungu e Diabo por Cariapemba, Céu por Cunezulu, Humanidade por Untu, pecado por Mafûmu/Masûmu e Penitência por Enzeoluêlo. Duas palavras tinham ainda grande probabilidade de produzir colisões culturais ao serem inseridos no vocabulário cristão ensinado aos africanos: batismo e padre, traduzidos respectivamente por Cudia Munga e Enganga.

Sacramento maior do catolicismo latino, o batismo supunha purificação e elevação espiritual na cerimônia que marcava a passagem dos neófitos para a vida cristã. Na medida em que as religiões africanas não dispunham em seus sistemas de valores de categorias hierárquicas do tipo alto/baixo, próprias da tradição judaico-cristã, a idéia forte de elevação se perdeu e o vocábulo escolhido apenas indicava um gesto fraco do ritual do batismo. Com efeito, a expressão Cudia Munga (Ku-dià Mungwa) significa, literalmente, "comer sal", numa provável alusão ao gesto integrante da cerimônia do batismo cristão (NSONDÉ, 1995, p. 176). Outra expressão a que os missionários recorriam para designar o batismo era Cusula Yanquissi, que significa, literalmente, "lavar de modo mágico", por vezes interpretada como "lavar segundo os preceitos de Deus".

Hist. R., Goiânia, v. 18, n. 1, p. 69-90, jan. / jun. 2013 
Mantinha-se todavia apenas a representação do gesto (lavar) e sua qualificação de ato mágico, e não a idéia de purificação e elevação pretendidos (NSONDÉ, 1992, pp. 706-707).

Quanto ao termo Enganga (Nganga), era utilizado no antigo Congo e no Ndongo para qualificar os sacerdotes, curandeiros e adivinhos providos de prestígio religioso, a todos os representantes das forças invisíveis e que, nessa condição, dispunham de poder (THORTON, 2008, p. 92). Eram eles os adversários e concorrentes a quem os missionários pretendiam eliminar quando difundiam a crença cristã, mas ao reivindicarem para si e para os padres este designativo, muito provavelmente passaram a ser vistos e reverenciados como tal pelas populações, isto é, como "feiticeiros brancos". Assumiam assim parte da responsabilidade pelo sincretismo afro-cristão que estava em gestação desde o início desses primeiros contatos.

Estudos recentes tem de fato demonstrado o quanto o cristianismo difundido na África central foi recebido mais por sua eficácia social do que por sua conotação espiritual diferenciada. A conversão limitava-se às populações, livres ou cativas, do litoral, e se fazia mais pelo grau de prestígio que conferia aos aderentes do que por convicções individuais, íntimas. Pelas denúncias das autoridades dos séculos XVII-XVIII pode-se dizer que as práticas africanas não apenas coexistiam, confundidas ou em paralelo, com os rituais do catolicismo, mas exerceram influência duradoura sobre as populações brancas e mestiças, transparecendo na forma de realização dos sacramentos, na comunhão, nos casamentos e sobretudo nos funerais, e as denúncias feitas perante os tribunais da Inquisição ilustram perfeitamente bem este aspecto. A fusão entre elementos cristãos e africanos manifestava-se em rituais denunciados como "pagãos" nas "casas de uso" (rituais de puberdade), adivinhações (xinguilamento), juramentos, poligamia, adoração a ídolos e circuncisão (HORTA, 1999, pp. 310-311) ${ }^{15}$. Nas palavras de Linda Heywood, muitos sobas que aderiram formalmente ao catolicismo usavam os objetos cristãos para ornamentar suas esposas, ou com a mesmo finalidade dos ídolos: “Os soberanos simplesmente seguiam as mesmas práticas com os objetos cristãos que usavam para com os símbolos religiosos locais, tornando-os símbolos políticos poderosos. Muitos incorporavam símbolos religiosos católicos em seus paramentos políticos" (HEYWOOD, 2008, p. 120). Foi o caso dos crucifixos (Nkangi Kiditu), amplamente 
adotados na indumentária dos chefes locais, tornando-se um entre outros símbolos de sua autoridade (MELLO E SOUZA, 2005, p.).

Não quer dizer que o cristianismo tenha deixado de produzir frutos na África central, mas não aqueles esperados pelos missionários. No período histórico aqui retratado ele irradiou a partir do Congo, enraizando-se e passando a fazer parte efetiva da cultura local no Ndongo e depois em Matamba, aceito pelos sobas e seus dependentes e aliados. Foi por isso que, já nesses primeiros séculos de contato, a força de seus elementos sincréticos gerou o primeiro movimento cristão genuino, o Antonianismo, pelo qual se expressava através da figura carismática da líder religiosa Dona Beatriz do Congo, ou Kimpa Vita (1684-1706), personificação de Santo Antônio, o dom mágico da profecia e uma perspectiva eminentemente messiânica. Era a primeira mostra indelével do cristianismo africano, que deveu algo ao catecismo em kikongo.

WrITING AND CONVERSION IN THE CENTRAL AFRICA IN THE $17^{\mathrm{TH}}$ CENTURY: THE KIKONGO’s CATECHISM OF 1624.

ABSTRACT: Since the thirteenth-fourteenth centuries, moment in which occurred the first missionary conversion movement of the pagan people in the East, one of the conditions to the evangelization was the knowledge of the non-Christian people's language. In the modern times, a great effort was dedicated to the learning of native languages of East India, of the New World and Africa, with their respective literalization e application in the Society of Jesus priests' catechetical works. It is intended to emphasize in this last aspect, from the introductory study of the dialogued catechism denominated Doutrina Christã written in 1566 by the Priest Marcos Jorge in Europe, and adapted to the Kikongo's language during the evangelizations works of the people from the ancient kingdom of Congo during the XVII century.

KEYWORDS: conversion, Kikongo's Catechism, Africa, 17th century.

ESCRITA Y CONVERSIÓN EN LA ÁFRICA CENTRAL DEL SIGLO XVII: EL CATECISMO KIKONGO DE 1624

RESUMEN: Desde los siglos XIII a XIV, momento en que se produjo el primero movimiento de conversión de los pueblos paganos en el Oriente, una de las condiciones para la evangelización fue el conocimiento de las lenguas de los pueblos no cristianos. En los tiempos modernos, un gran esfuerzo se ha dedicado al aprendizaje de los idiomas nativos de las Indias Orientales, del Nuevo Mundo y de África, con su respectiva literalización y la aplicación en la obra catequética por los sacerdotes de la Compañía de Jesús. Se pretende

Hist. R., Goiânia, v. 18, n. 1, p. 69-90, jan. / jun. 2013 
hacer hincapié en este último aspecto desde el estudio introductorio del catecismo dialogado, llamado Doutrina Christã, escrito en 1566 por el Sacerdote Marcos Jorge, en Europa, y adaptado a la lengua kikongo durante la evangelización de los pueblos del antiguo reino del Congo a lo largo del siglo XVII.

PALABRAS CLAVE: Conversión, catecismo kikongo, África, siglo XVII.

\section{NOTAS}

${ }^{1}$ Ao que parece, a única edição do documento deve-se a Bontick e não foram encontrados quaisquer estudos específicos sobre ele, e nem mesmo informações mais detalhadas.

2 Nos sistemas de comunicação estabelecidos entre europeus, africanos e demais povos contatados no contexto da expansão marítima convém distinguir as iniciativas laicas, de parte dos governantes portugueses, no sentido de criar agentes locais conhecedores da língua metropolitana, das iniciativas religiosas visando o conhecimento direto das línguas locais, com a dispensa dos intérpretes, que era uma condição para a conversão.

3 Na interpretação de Gonçalves (2005) as medidas tomadas por Afonso I alteraram significativamente o modelo político-social até então vigente no Congo, criando uma nova realidade política e introduzindo noções inexistentes até então, sobretudo: a idéia de uma territorialidade associada a sua autoridade como governante; a noção de uma sucessão dinástica em linha direta, por descendência em linha patrilinear; a concessão de títulos de nobreza e a formação de uma corte; a unidade político-cultural através do modelo fornecido pelo cristianismo.

${ }^{4}$ Outro texto importante do período pré-tridentino, em Portugal, foi a Ordem e Regimento de Vida Cristã, de Frei Pedro de Santa Maria, escrito em Coimbra no ano de 1555.

5 Atualmente, ela conta com mais de 20 variantes, como as línguas kikunyi, kidondo, kikamba, civili, kibembe, cisundi, kilaadi, kisigombe, kiyombe, ndingi, kintandu, kisombo e kinsoso.

${ }^{6} \mathrm{O}$ primeiro exemplo nesse sentido encontra-se na correspondência trocada entre Afonso I e os reis portugueses Manuel I e João III.

7 A documentação escrita sobre o Congo e o Ndongo, etnocêntrica quanto à forma e cristocêntrica quanto aos valores morais, é o que os etnógrafos e historiadores dispõem como evidências para reconstituir as práticas sócio-culturais e religiosas dos primeiros séculos de contato. Por maior que sejam os obstáculos para sua interpretação, nem tudo nela resulta de estereótipos ou representações, e não nos parece que a desconfiança em seus dados seja o melhor caminho para a interpretação do seu significado.

8 Para as relações entre jesuítas e indígenas, o aporte conceitual mais significativo para problematizar os níveis de comunicação e trocas culturais deve-se a Castro (2002) A incompreensão dos sistemas de valores dos povos africanos também levou a que, no discurso missionário, se desenvolvesse o topos da predisposição inata dos africanos ao cristianismo e, subsequentemente, de sua inconstância e abandono da crença. Todavia os sistemas de valores dos indo-americanos e africanos não são os mesmos e, em nosso caso, o melhor será verificar, tanto quanto possível, sob o verniz do texto euro-cristão, que ou quais elementos culturais seriam inerentes às culturas centroafricanas.

${ }^{9}$ Um dos mais importantes mediadores culturais da primeira metade do século XVII foi o frade Manuel Roboredo, filho de mãe africana e pai português, que ocupou a função de capelão oficial dos manicongo e atuava como seu intérprete nas relações com os europeus. Seu papel junto aos capuchinhos foi decisivo para a implantação da missão, e deve-se a ele a redação de documentos em kikongo Ao que parece, a única edição do documento deve-se a Bontick e não foram encontrados quaisquer estudos específicos sobre ele, e nem mesmo informações mais detalhadas. Nos sistemas de comunicação estabelecidos entre europeus, africanos e demais povos contatados no contexto da expansão marítima convém distinguir as iniciativas laicas, de parte dos governantes portugueses, no sentido de criar agentes locais conhecedores da língua metropolitana, das iniciativas religiosas visando o conhecimento direto das línguas locais, com a dispensa dos intérpretes, que era uma condição para a conversão. Atualmente, ela conta com mais de 20 variantes, como as línguas kikunyi, kidondo, kikamba, civili, kibembe, cisundi, kilaadi, kisigombe, kiyombe, ndingi, kintandu, kisombo e kinsoso. O primeiro exemplo nesse sentido encontra-se na correspondência trocada entre Afonso I e os reis portugueses Manuel I e João III.

José Rivair Macedo. Escrita e conversão na África Central do século XVII: o catecismo Kikongo de 
${ }^{10}$ Esta leitura era difundida em obras escritas em Portugal no período colonial e se projeta em algumas obras atuais, de autores como: Brasio, Rego e Rema.

${ }^{11} \mathrm{Na}$ vasta zonas de influência cultural banto, que abrange a África central e a África austral, todas as línguas servemse de um vocábulo genérico para se referirem ao que os cristãos designam Deus, porque concebem que a própria enunciação do nome equivaleria a uma manipulação da essência divina. Contam-se pelo menos 23 nomes diferentes para a designação do ente supremo, e na região de Angola, o mais comum é o emprego da palavra Nzambi, em suas inúmeras variantes (Nyambe, Njambe, Nzame, Nzama, etc).

${ }^{12}$ Este aspecto era notado desde os primeiros contatos com os portugueses, como se pode ver nas palavras de Baltazar Rebelo de Aragão, escritas em 1618: "Todo esse gentio toma bem a fé e se fariam com muita facilidade cristãos, por não terem ídolos nem lei alguma; reconhecem a Deus e ao Diabo e sabem que há inferno e paraíso; algumas estátuas a que tem reverência não são de Deus, senão de seus antepassados e avós, e cada qual tem a sua, mas não por lei nem obrigação".

${ }^{13}$ Sobre os problemas de terminologia e de interpretação nas traduções dos antigos missionários, e as soluções adotadas pelos teólogos do século XX, o estudo de Valente (1973), tem em conta as traduções modernas do português ao umbundo.

14 Observa que "Tupã está longe de ser uma noção implicando a idéia do sagrado. É uma espécie de gênio ou demônio, que não era objeto de nenhum culto e ao qual não se dirigia nenhuma prece".

${ }^{15} \mathrm{O}$ uso dos sinais cristãos como fetiches, conhecidos na região pelo termo genérico nkisi, aparece com freqüência em denúncias feitas ao tribunal de Inquisição em Luanda.

\section{REFERÊNCIAS}

Arte da lingva de Angola offerecida a Virgem Senhora N. do Rosário, mãy \& Senhora dos mesmos pretos, pelo P. Pedro Dias da Companhia de Jesu. Lisboa: Na officina de Miguel Deslandes, 1697. Disponível em: http://archive.org/details/artedalinguadean00dias. Acesso em 03/10/2012.

ALMEIDA, Carlos José Duarte. “A representação do africano na literatura missionária sobre o reino do Kongo e Angola (meados do século XVI - meados do século XVII)". Dissertação de Mestrado em História dos Dscobrimentos e da Expansão Portuguesa. Lisboa: FCSH-UNL, 1997.

ALTUNA, Raul de Asúa. Cultura tradicional banto. 2a edição. Luanda: Ed. Paulinas, 2006, p. 399.

ANCHIETA, José de. Arte de grammatica da lingoa mais vsada na costa do Brasil. Disponível no acervo digital Brasiliana USP: http://www.brasiliana.usp.br/bbd/handle/ 1918/00059200 \#page/1/mode/1up Acesso em 10 de maio de 2011.

BARROS, Maria Cândida Drumond Mendes. "Notas sobre os catecismos em línguas vernáculas das colônias portuguesas (séculos XVI-XVII). Ibero-Romania: Zeitschrift fur Spanische, Portugiesische und Katalanische Sprache um Literatur (Munique), nº 57, 2003, pp. 27-63.

BARROS, Maria Cândida Drumond Mendes. "Entre heterodoxos e ortodoxos: notas sobre os catecismos dialogados na Europa e nas colônias no século XVI'. Fênix: Revista de História e Estudos Culturais, ano V, vol $5 \mathrm{n}^{\circ}$ 4, 2008, p. 13.

Hist. R., Goiânia, v. 18, n. 1, p. 69-90, jan. / jun. 2013 
BIRMINGHAM, D.. A conquista portuguesa de Angola. Porto: A Regra do Jogo, 1974; BONTICK, François. Le catéchisme kikongo de 1624. Bruxelles: Academie Royale des Sciences d'Autre Mer, 1978.

BONVINI, Emilio. "Linguas africanas e português falado no Brasil”. In: FIORI, José Luís;

BRÁSIO, António. “Os proto-missionários no Congo”. Portugal em África: Revista de Cultura Missionária (2 série), vol. I, 1944, pp. 99-112;

BRÁSIO, António. "Política do espírito no ultramar português". Portugal em África, 2a série, ano VI no 31, 1949, pp. 20-290, 75-86, 209-222;

CASTRO, Eduardo Viveiros de. "O mármore e a murta: sobre a inconstância da alma selvagem”. In: IDEM. A inconstância da alma selvagem e outros ensaios de antropologia. São Paulo: cosac \& Naify, 2002, pp. 181-164.

COHN, Norman. Los demonios familiares en Europa. Madrid: Alianza, 1982

CORDEIRO, Luciano (ed). "Terras e minas africanas segundo Baltasar Rebelo de Aragão, 15931631”. In: IDEM. Questões Histórico-coloniais. Lisboa: Agência Geral das Colónias, 1935, vol. I, p. 224.

CRISTOVÃO, Francisco da Silva. "O Cathecismo pequeno de D. Diogo Ortiz Vilhegas". Hvmanitas (Lisboa), vol. L, 1998, pp. 687-700

CURTO, Diogo Ramada. “O sistema do escravo-intérprete”. In: IDEM. Cultura imperial e projetos coloniais (séculos XV a XVIII). Campinas: Editora da UNICAMP, 2009, pp. 38-42.

. “A língua e o império". In: BETHENCOURT, Francisco; KIRTI, Chauduri (dirs). História da expansão portuguesa. Lisboa: Círculo de Leitores, 1998, vol. I, pp. 419-421. CURTO, Diogo Ramada . "Do Reino à África - formas dos projetos coloniais para Angola em inícios do século XVII". In: FURTADO, Junia Ferreira (org). Sons, formas, cores e movimentos de modernidade atlântica: Europa, Américas e África. São Paulo: Annablume, 2008, pp 187-217, esp. pp. 197-198.

DAHER, Andrea. "Écrire la langue indígene. La grammaire tupi et les catéchismes bilingües au Brésil (XVI siècle)". Mélanges de l'École Française de Rome. Italie et Mediterranée (Roma), tome 111-1, 1999, pp. 232-236

DAINELLI, Giotto. Missionari e mercadanti rivelatori dell'Asia nel Medioevo. Torino: Unione Tipografico-Editrice, 1960.

José Rivair Macedo. Escrita e conversão na África Central do século XVII: o catecismo Kikongo de 1624. 
Doutrina Christaã, composta pelo P. Marcos Jorge, da Companhia de IESU, doutor em Teologia, acrescentada pelo Padre Ignácio Martinz, da mesma Companhia, doutor theologo. De novo traduzida na lingoa do Reyno de Congo, por ordem do P. Mattheus Cardoso, theologo da Companhia de IESU, natural da cidade de Lisboa. Lisboa, Por Geraldo da Vinha, 1624. BNL, res. 268.

Doutrina christam ordenada a maneira de dialogo para ensinar os mininos. Disponível em http://books.google.com.br Acesso em 15/09/2012.

FERRONHA, António Luís Alves (trad). As cartas do rei do Congo D. Afonso. Lisboa: Comissão Nacional para as Comemorações dos Descobrimentos Portugueses, 1992.

GONÇALVES, Rosana Andréa. "África indômita: missionários capuchinhos no reino do Congo (século XVII)”. Dissertação de Mestrado - FFLCH-USP, 2008.

GONÇALVES, António Custódio.. "Kimpa Vita: simbiose de tradição e modernidade”. In: Actas do Seminário - Encontro de povos e culturas em Angola (Luanda, 3 a 6 de Abril de 1995). Lisboa: Comissão Nacional para as Comemorações dos Descobrimentos Portugueses, 1999, pp. 323-338.

HEYWOOD, Linda M.. "De português a africano: a origem centro-africana das culturas atlânticas crioulas no século XVIII". In: IDEM (org). Diáspora negra no Brasil, São Paulo: contexto, 2008.

HILTON, Anne. "European sources for the study of religious change in sixteenth and seventeenth century Kongo". Paideuma, no 33, 1987, pp. 289-312.

HORTA, José da Silva. “A imagem do africano pelos portugueses antes dos contactos”, pp. 55-58; "Primeiros olhares sobre o africano do Sara Ociental à Serra Leola (meados do século XV - inícios do século XVI”, pp. 108-109, In: FERRONHA, António Luiz (dir.). O confronto do olhar: o encontro dos povos na época das navegações portuguesas. Lisboa: Ed. Caminho, 1991.

HORTA, José da Silva. Africanos e portugueses na documentação inquisitorial de Luanda a Mbanza Kongo (1596-1598). In: VVAA. Actas do Seminário - Encontro de povos e culturas em Angola (Luanda, 3 a 6 de Abril de 1995). Lisboa: Comissão Nacional para as Comemorações dos Descobrimentos Portugueses, 1999,

KINDALE, Richard P.. (Ed). Los lucidarios españoles. Madrid: Gredos, 1968.

KLEINE, Marina. Os missionários franciscanos e o problema da comunicação com os 'infiéis' nos séculos XIII-XIV. In: MACEDO, José Rivair (org). Os viajantes medievais da Rota da Seda. Porto Alegre: EDUFRGS, 2011, pp. 135-152.

Hist. R., Goiânia, v. 18, n. 1, p. 69-90, jan. / jun. 2013 
MANUEL, Ndonga Mfuwa. A língua kìkôngo: uma breve apresentação. Kulonga: Revista das Ciências da Educação e Estudos Multidisciplinares (Luanda), nº 1, 2002, pp. 148-169.

MARTINES, Jesus Montoya. La edicion de los catecismos en el Nuevo Mundo. In: VVAA. Bartolomeu Dias e sua época (Actas). Porto: Universidade do Porto; Comissão Nacional para as Comemorações dos Descobrimentos Portugueses, 1989, vol. V, p. 427.

MARTINS, Leopoldo Pires (Ed). Catecismo Romano: versão fiel da autêntica de 1566, com notícia bhistórica e análise crítica. Petrópolis: Vozes, 1951, pp. 18-20.

MELLO E SOUZA, Marina. Evangelização e poder na região do Congo e Angola: a incorporação dos crucifixos por alguns chefes centro-africanos, séculos XVI-XVII. In: Actas do Congresso Internacional Espaço Atlântico de Antigo Regime: poderes e sociedades (Lisboa, 02 a 05 de novembro de 2005). Disponível em Biblioteca Digital Camões: http://cvc.institutocamoes.pt/eaar/coloquio/comunicacoes/marina_mello_souza.pdf Acesso em 12/04/2013.

MÉTRAUX, Alfred. A religião dos tupinambás São Paulo: Companhia Editora nacional, 1950. Coleção Brasiliana no 267.

MONTEIRO, Fernando Amaro. Do ente supremo na revelação judaico-cristã, na revelação corânica e na religião tradicional africana (Ajauas e Macuas como exemplo). Africana (Centro de Estudos Africanos - Universidade Portucalense), n 9, 1991, pp. 7-23.

NSONDÉ, Jean de Dieu. Langues, culture et histoire koongo aux XVII et XVIII siècles. Paris: Harmattan, 1995, pp. 58-59.

NSONDÉ, Jean. Christianisme et religion traditionelle em pays koongo aux XVII-XVIII siècles. Cahiers d'Études Africaines (Paris), vol. 32 n. 128, 1992, pp. 706-707.

PETTER, Margarida. A presença de línguas africanas na América Latina. Linguística (Montevidéu), vol. 26, 2011, pp. 78-96

PETTER, Margarida (Eds). África no Brasil: a formação da língua portuguesa. São Paulo: Ed. Contexto, 2008, pp. 15-62

Repères pour une histoire des connaissances linguistiques de langues africaines: I - du XVI siècle au XVIII siècle: dans le sillage des explorations. In : Histoire. Epistemologie. Langage (Paris), tome $18 \mathrm{n}^{\circ} 2,1996$, pp. 127-148.

RANDLESS, W. G. L.. L'ancien royaume du Congo, des origenes a la fin du XIX siécle. Paris: Mouton \& co, 1968.

José Rivair Macedo. Escrita e conversão na África Central do século XVII: o catecismo Kikongo de 1624. 
REMA, Henrique Pinto. “As missões católicas portuguesas no Atlântico Sul no século XVII". Itinerarium: revista quadrimestral de cultura (Lisboa), vol. XLIII nº 159, 1997, p. 526.

REMA, Henrique Pinto. “Aculturação e inculturação na gesta dos descobrimentos portugueses”. Itinerarium: revista quadrimestral de cultura (Lisboa), vol. XLVII nº 171, 2001, pp. 481-500.

REGO, A. da Silva. Alguns problemas sociológico-missionários da África Negra. Lisboa: Junta de Investigações do Ultramar, 1960, esp. pp. 68-72.

RICHARD, Jean. “L'enseignement des langues orientales en Occident au Moyen Âge”. In: Colloques internationaux de La Napoule, Islam et Occident au Moyen Âge. Revue des Études Islamiques, XLIV, 1976.

ROSA, Maria Carlota. “A Arte da língua de Angola (1697) e a Gramática Latina de Manuel Álvares (1572)”. Eutomia: Revista Online de Literatura e Linguística, ano III, vol. 2, 2010. Disponível online: $\quad$ http://www.revistaeutomia.com.br/volumes/Ano3-Volume2/especialdestaques/destaques-linguistica/destaque_a_arte_da_lingua_de_angola.pdf $\quad$ (acessado em 03/10/2012).

SALDANHA, Mariano (ed). Doutrina cristã em língua concani por Tomás Estevão, SJ, impressa em Rachol (Goa) em 1622. Segunda edição fac-similada. Lisboa: Agência Geral das Colónias Divisão de Publicações e Bibliotecas, 1949.

SANTOS, Catarina Madeira. "Escrever o poder: os autos de vassalagem e a vulgarização da escrita entre as elites africanas Ndembu". Revista de História (USP), n 155-2, 2006, pp. 81-95.

SCHMITT, Jean-Claude. Historia das superstições (Fórum da História). Mem Martins: Publicações Europa América, 1997.

SOUZA, Marina de Mello e. Religiões tradicionais e catequese na África central, século XVII. Phronésis (Campinas), vol. 8 n. 1, 2006, pp. 121-138

TAVARES, Ana Paula; SANTOS, Catarina Madeira (Ed., intr., glossário e textos). Africae Monumenta. A apropriação da escrita pelos africanos. Lisboa: Instituto de Investigação Científica Tropica - IICT, 2002.

TAVARES, Lourenço. Gramática kiikongo (dialecto kisolongo). $2^{\circ}$ edição. Luanda: Imprensa Nacional da colônia de Angola, 1934.

TAVARES, Pedro Vilas Boas. Algumas notas sobre o 'catecismo peninsular' no século XVI. De Constantino a Frei Pedro de Santa Maria. Revista da Faculdade de Letras - Línguas e literaturas (Universidade do Porto), vol. I, 1984, pp. 262-276. 
THORTON, John. Documentos escritos e tradição oral num reino alfabetizado: tradições orais escritas no Congo, 1580-1910. In: VVAA. Construindo o passado angolano - as fontes e sua interpretação (Actas do II Seminário Internacional sobre a História de Angola). Lisboa: Comissão para as Comemorações dos Descobrimentos Portugueses, 1996, pp. 446-465.

THORTON, John. A África e os africanos na formação do mundo atlântico: 1400-1800. Rio de Janeiro: Rio de Janeiro: Ed. Campus; Ed. Elsevier, 2004.

Religião e vida cerimonial no Congo e áreas umbundo, de 1500 a 1700. In: Linda M. HEYWOOD (org). In: HEYWOOD, Linda M. (org). Diáspora negra no Brasil. São Paulo: contexto, 2008.

. The congolese Saint Anthony. Dona Beatriz Kimpa Vita and the antonian movement, 1684-1706. Cambridge: Cambridge University Press, 1998.

VAINFAS, Ronaldo; SOUZA, Marina de Mello e. Catolização e poder no tempo do tráfico: o reino do Congo da conversão coroada ao movimento antoniano, séculos XV-XVIII. Tempo (Universidade Federal Fluminense), vol 3 nº 6, 1998.

VALENTE, Francisco. Africanismo ou ocidentalismo na terminologia litúrgica. Portugal em África (Lisboa), no 175-178, 1973, pp. 183-228.

VANSINA, J. Les anciens royaumes de la savane: les etats des savanes méridionales de l'Afrique centrale des origines à l'occupation coloniale. Léopoldville (Congo): Institut de Recherches Economiques et Sociales, 1965, pp. 100-110.

VIEGAS, Arthur (ed). Relação anual das coisas que fizeram os padres da Companhia de Jesus nas suas missões, nos anos de 1600 a 1609, pelo padre Fernão Guerreiro. Coimbra: Imprensa da Universidade, 1930, vol. I, p. 398.

WOORTMANN, Klaas. O selvagem e a Gesta Dei: história e alteridade no pensamento medieval. Revista Brasileira de História (São Paulo), vol. 25 n 50, 2005, pp. 259-314.

ZUPANOV, Ines G.. Mission linguistique. L'indigenisation du verbe em pays tamoul (XVI-XVII siècles). Archives des Sciences Sociales des Religions (Paris), nº 103, 1998, pp. 43-65.

ZWARTJES, Otto. Portuguese missionary grammars in Asia, Africa and Brazil, 1550-1800. Amsterdam; Philadelphia: John Benjamin Publishing Company, 2011.

José Rivair Macedo. Escrita e conversão na África Central do século XVII: o catecismo Kikongo de 1624. 